\title{
KRIVIČNO DJELO ZLOČIN PROTIV ČOVJEČNOSTI U PRAVOMOĆNIM PRESUDAMA ZA ZLOČINE POČINJENE NA PROSTORU BOSANSKE KRAJINE
}

\section{Sažetak}

Krivično djelo zločin protiv čovječnosti u pravomoćnim presudama izrečenim osobama za zločine počinjene na prostoru Bosanske krajine predstavlja najčešću krivičnu sankciju izrečenu pred Međunarodnim krivičnim sudom za bivšu Jugoslaviju (dalje u tekstu MKSJ) i Sudom Bosne i Hercegovine (dalje u tekstu Sud BiH). Zločin protiv čovječnosti usmjeren je prema vrijednostima karakterističnim za čitavo čovječanstvo, odnosno prema opće civilizacijskim vrijednostima. Definiranjem ovog krivičnog djela u Statutima medunarodnih

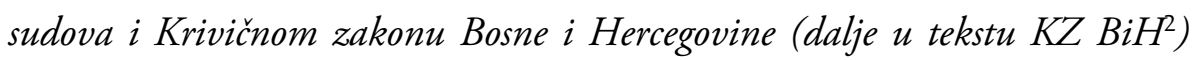
omogućuje se kažnjavanje teških kršenja ljudskih prava koji su produkt šire zločinačke politike. U našem krivičnom zakonodavstvu ovo krivično djelo nije bilo obuhvaćeno Krivičnim zakonom SFRJ (dalje u tekstu KZ SFRJ), već je definirano $\mathrm{KZ} \mathrm{BiH}$. Iako zločin protiv čovječnosti do pojave $\mathrm{KZ}$ BiH nije bio definiran KZ SFRJ neki oblici krivičnog djela zločin protiv čovječnosti sadrže identična djela koja su ranije bila definirana kao djela ratnog zločina protiv civilnog stanovnistva, ako su učinjena za vrijeme rata, oružanog sukoba ili okupacije. Bez obzira što ovo krivično djelo predstavlja novinu u krivičnom zakonodavstvu BiH pred Sudom BiH izrečen je odreden broj krivičnih sankcija upravo za ovo jedno od najtežih krivičnih djela. Jedan broj pravomoćnih presuda izrekao je i MKSJ za zločine počinjene na prostoru Bosanske krajine. Istovremeno definiranjem ovog krivičnog djela, BiH je ispunila svoju medunarodno pravnu $i$ ustavnu obavezu. $U$ ovom radu je ponudena analiza bitnih elemenata krivičnog djela zločin protiv čovječnosti sa

\footnotetext{
${ }^{1}$ Institut za nestale osobe $\mathrm{BiH}$

${ }^{2} \mathrm{KZ}$ BiH usvojen je 1. marta 2003. godine (Službeni Glasnik BiH br. 3/03), prečišćeni tekst objavljen je u "Službenom glasniku $\mathrm{BiH}$ br. 37/ 03, izmjene i dopune su vršene u nekoliko navrata i objavljene su u "Službenim glasnicima br. 54/04 i 61/04.
} 
posebnim osvrtom na pravomoćne presude izrečene za zločine počinjene na prostoru Bosanske krajine.

Ključne riječi: zločin protiv čovječnosti, medunarodno humanitarno pravo, rat, oružani sukob, civilno stanovništvo, ubistvo, istrebljenje, odvodenje u ropstvo, deportacija, zatvaranje, mučenje, silovanje, progoni, nečovječno djela.

\section{Uvodne napomene}

Krivično djelo zločin protiv čovječnosti je krivično djelo koje je predviđeno članom 172. KZ BiH i odnosi se na grupu krivičnih djela koja se nazivaju međunarodnim krivičnim djelima i sadržana su u glavi XVII KZ BiH. Inače djela sadržana u ovoj glavi, svoju međunarodnu osnovu za inkriminaciju imaju u različitim Konvencijama ${ }^{3}$ koje imaju svoju historijski razvoj. Ratni zločini definiraju se kao teška kršenja običajnih ali i ugovornih pravila koja spadaju u korpus međunarodnog humanitarnog prava ratnih sukoba. ${ }^{4}$ Početke razvoja međunarodnog humanitarnog prava možemo posmatrati u kontekstu nastojanja da se određenim ugovorima definiraju i propišu pravila ratovanja koja bi obavezivala zaraćene strane na humano postupanje ne samo prema učesnicima $u$ sukobu nego i prema civilnom stanovništvu. Države potpisnice takvih međunarodnih instrumenata preuzele su obavezu da svojim nacionalnim krivičnim zakonodavstvom ili neposrednom primjenom tih instrumenata osiguraju primjenu pravila o postupanju za vrijeme rata ili oružanog sukoba. ${ }^{5}$ Potpisivanje međunarodnih konvencija i ugovora predstavlja

\footnotetext{
${ }^{3}$ Međunarodne konvencije su najvažniji izvor međunarodnog krivičnog prava. U oblasti međunarodnog krivičnog prava postoji velik broj konvencija (neki autori govore o preko 300 instrumenata međunarodnog krivičnog prava). Norme koje propisuju konvencije u ovoj oblasti ne mogu se najčešće direktno primjenjivati (usljed toga što su odredbe relativno uopštene i ne propisuju sankcije), već se po ratifikaciji ovih dokumenata vrši odgovarajuća izmjena nacionalnog krivičnog zakonodavstva.

${ }^{4}$ Antonio Kaseze, Mecunarodno krivično pravo, Dosije, Beograd, 2005, str. 53.

${ }^{5}$ Zvonimir Tomić, Krivično pravo II-posebni dio, Pravni fakultet Sarajevo, Sarajevo, 2007, str. 413.
} 
osnovu za inkriminaciju ovih krivičnih djela u nacionalnim zakonodavstvima i kažnjavanje počinilaca istih.

U suštini međunarodno humanitarno pravo ima za cilj humaniziranje ratovanja odnosno, umanjenje patnji, tortura, sprečavanje okrutnosti, ubijanja i razaranja materijalnih dobra. Međutim, potpuna humanizacija rata značila bi da ratovi kao društvena pojava uopće ne postoje. Stoga je humanizacija rata ograničena njegovom svrhom koja se ogleda $u$ postizanju vrhunskih ratnih ciljeva, uključujući i konačnu pobjedu nad neprijateljem. ${ }^{6}$

Pravna pravila o ratovanju i zaštiti osoba u ratnim sukobima razvijala su se stoljećima kao pravila nepisanog običajnog prava. Ratovi kao društvena pojava od najranijih perioda razvoja ljudskog društva vođena su po nekim običajnim pravilima. Tako je i Sun-Cu u knjizi iz četvrtog stoljeća p.n.e "Umijeće ratovanja" opisao običaje o postupanju s ranjenicima i starim licima. Nastavak običajnog prava ratovanja imamo prije svega u pravilima viteškog ratovanja (riterska pravila) "koja se nisu poštovala u ratovima protiv nevjernika, a ni pri gušenju seljačkih i drugih buna." ${ }^{7}$ Nastojanja da se definiraju i spriječe najgora postupanja i zločini u ratu imamo od početkom 11. stoljeća do danas. ${ }^{8}$ Međutim, koliko su poštovana i primjenjivana to je potpuno suprotno od prvobitnih intencija. U savremenim ratovima nimalo značajnim se nisu smatrali niti ljudski životi, niti materijalna dobra. Kako bi se promijenilo takvo haotično stanje na terenu, a i u oblasti ratnog prava, pojavila se potreba za njegovom kodifikacijom.

\footnotetext{
${ }^{6}$ Vladimir Đuro Degan, Međunarodno pravo, Pravni fakultet Sveučilišta u Rijeci, Rijeka, 2000, str. 828 .

${ }^{7}$ Isto, str. 825 .

${ }^{8}$ Postoje određeni crkveni propisi koji ograničavaju privatne ratove među feudalcima, zatim postojali su dani u kojima je bilo zabranjeno ratovanje, kao npr. primirje od zalaska sunca srijedom do izlaska sunca ponedjeljkom.
} 
Pod pritiskom javnosti ${ }^{9}$ polovinom devetnaestog vijeka počelo se sa kodifikacijom međunarodnog ratnog prava putem pisanih ugovora, i ovaj proces se razvijao od ratnog ka humanitarnom pravu. Savremenim razvojem tehnike i tehnologije koja je najčešće imala primjenu za vojne potrebe javila se potreba za kodifikacijom međunarodnog humanitarnog prava u novim okolnostima, ${ }^{10}$ jer u tim uslovima i okolnostima ratovanja, ratovi postaju sve više necivilizirani i nehumani. Kada je riječ o kodifikaciji ratnog prava ono je "imalo za prvobitni cilj da po mogućnosti sve države svijeta postanu strankama tih konvencija u pisanom obliku i da one po ugovornoj osnovi obavezuju sve zaraćene strane u svim budućim ratovima. Dalje je cilj bio da se preciziraju prava i dužnosti strana u oružanim sukobima, da bi se spriječilo da svako za sebe, i za suprotnu stranu proizvoljno tumači pravila ratnog prava ovisno o svojim trenutnim interesima." 11

Bosna i Hercegovina je propisujući u nacionalnom zakonodavstvu da kršenje određenih pravila međunarodnog prava propisanih međunarodnim konvencijama koje je ratifikovala, predstavlja krivično djelo, što je ujedno i njena međunarodna i ustavna obaveza. Aneksom I Ustava $\mathrm{BiH}$ u Dodatnom Sporazumu o ljudskim pravima ugrađena je Konvencija o sprječavanju i kažnjavanju zločina genocida od 9 . decembra 1948. godine, Konvencije o zaštiti žrtava rata I-IV od 12. augusta 1949. godine i Dopunski Protokoli I i II od 8. juna 1977. godine. Također, KZ $\mathrm{BiH}$ u jednom dijelu prihvatio je i ugradio krivična djela (zločin protiv čovječnosti) sadržana u Rimskom statutu Međunarodnog krivičnog suda

\footnotetext{
${ }^{9}$ Henri Dunant je potaknuo javnost jer je bio svjedok bitke kod Solferina 1859. godine između francuske i austrijske vojske kada je poginulo preko 30.000 ljudi, većina njih je iskrvarila a dio ranjenika je pokopan živ. Zahvaljujući njemu i njegovoj brošuri «Un souvenir de Solferino» iz 1862. godine došlo je do organiziranja nacionalnih društava Crvenog križa, i usvajanje prve konvencije o poboljšanju sudbine ranjenika u vojskama na kopnu, potpisane u Ženevi 22. avgusta 1864. godine.

${ }^{10}$ Razvoj savremenog nuklearnog naoružanja i strahote njihove upotrebe na Hirošimu i Nagasaki ukazale su na potrebu usvajanja određenih Konvencija o zabranama i ograničenjima upotrebe nuklearnog naoružanja.
}

${ }^{11}$ V. Đ. Degan, nav. dj., str. 828. 
koji ima nadležnost da sudi za: zločin genocida, zločin protiv čovječnosti, ratne zločine i zločine agresije.

Rat kao društvena pojava u kojoj je dehumanizacija čovjeka u prvom planu, izražava se kroz ubijanja, nanošenje teških tjelesnih i psihičkih povreda i patnji, povrede dostojanstva i ličnosti, protupravno oduzimanje slobode, imovine jednom riječju nečovječnim postupanjem odnosno postupanjima koja nisu u skladu sa pravilima međunarodnog prava. "Čovječnost kao zaštitni objekt obuhvaća poštivanje ljudskih prava i sloboda, kako u vrijeme mira, tako i za vrijeme rata ili oružanog sukoba."12 Na prostoru Bosne i Hercegovine svjesno, planski, organizirano i masovno su kršena pravila međunarodnog prava. Jedan broj počinilaca krivičnih djela protiv čovječnosti i međunarodnog prava, pravomoćno je osuđen pred Međunarodnim krivičnim sudom za bivšu Jugoslaviju (dalje u tekstu MKSJ), Sudom BiH, kantonalnim i okružnim sudovima.

\section{Međunarodno pravno definiranje zločina protiv čovječnosti u Statutima međunarodnih sudova}

Zločin protiv čovječnosti kao pojam pominje se puno prije nego što je definiran u Statutu Nirnberškog suda i Zakonu 10 o kažnjavanju osoba odgovornih za ratne zločine, zločine protiv mira i čovječnosti (Berlin 1945. godine). Ovaj pojam se koristi od Martensove klauzule, izjave vlada Francuske, Rusije i Velike Britanije 1915. godine povodom zločina nad Jermenima, ${ }^{13}$ također Oppenheim pominje pojam zločin protiv čovječnosti. ${ }^{14}$ Ovaj pojam u međunarodnom pravu je široko definiran $u$ više međunarodnih Statuta. Ratni zločini mogu biti počinjeni u: međunarodnim oružanim sukobima ${ }^{15}$ i $u$ unutrašnjim oružanim

\footnotetext{
12 Z. Tomić, nav. dj., str. 414.

${ }^{13}$ Vidjeti Vahakn Dadrian, The History of the Armenian Genocide (1995).

${ }^{14}$ Lassa Oppenheim, International law, Vol.1, treće izdanje, 1920, str. 229.

15 Sukob između dvije ili više država, odnosno između država i narodnooslobodilačkih pokreta (Dopunski protokol I iz 1977, član 1, stav 4)
} 
sukobima. ${ }^{16}$ Postojala su određena stajališta da inkriminiranje ratnih zločina u unutrašnjim oružanim sukobima nije potrebno, da ratni zločini mogu biti samo počinjeni u međunarodnim oružanim sukobima. ${ }^{17}$ Zločin protiv čovječnosti definiran je u više Statuta Međunarodnih sudova ali i $\mathrm{KZ} \mathrm{BiH}$, iz tog razloga zločin protiv čovječnosti kao krivično djelo treba sagledati u ovim Statutima i KZ BiH kako bi se izvršilo poređenja i ukazalo na određene razlike u definiranju.

\section{a) zločin protiv čovječnosti u Statutu Nirnberškog suda i Zakona br.10. Kontrolnog savjeta}

Statutom Nirnberškog suda ${ }^{18}$ u članu 6 (c) zločin protiv čovječnosti definiran je kao: ubistvo, istrebljenje, porobljavanje, deportacija i ostala nečovječna djela, izvršena protiv bilo kog civilnog stanovništva prije ili za vrijeme trajanja rata. Zločin protiv čovječnosti je i proganjanje na političkoj, rasnoj ili vjerskoj osnovi u izvršenju ili u vezi bilo kojeg zločina koji spada u nadležnost Suda, bez obzira vrše li se tim ili ne vrše povrede zakona one zemlje u kojoj su zločini izvršeni. ${ }^{19}$

\footnotetext{
${ }^{16}$ Sukob većih razmjera između oružanih snaga jedne države i otpadničkih oružanih snaga ili drugih organiziranih naoružanih grupa koje pod odgovornom komandom vrše neprekidne i usmjerene vojne operacije (Dopunski protokol II iz 1977, član 1 stav 1). Ovaj Protokol ne primjenjuje se na unutrašnje nemire, pobune i druge izolirane i sporadične akte nasilje jer to nisu oružani sukobi (Dopunski protokol II, član 1 stav 2).

17 Suprotno ovakvim stajalištima Žalbeno vijeće MKSJ u predmetu Tadić izrazilo je stajalište da ratni zločini mogu biti počinjeni i u unutrašnjim oružanim sukobima. ICTY, Presuda pretresnog vijeća protiv Duška Tadića, Predmet: IT-94-1, Den Haag, 16. juli 1997.

${ }^{18}$ Formiranje Međunarodnog vojnog suda u Nürnbergu počelo je na osnovu londonskog Sporazuma o progonu i kažnjavanju ratnih zločinaca potpisanog u augustu 1945. godine između SAD, Francuske, V. Britanije i SSSR. Nakon toga donesen je i Statut Međunarodnog vojnog suda koji je proglašen sastavnim dijelom Sporazuma. Ovim je stvoren pravni osnov za procesuiranja (nadležnost i sastav suda te pravila postupka) ratnih zločina.

${ }^{19}$ Zbirka propisa, Mecunarodne konvencije o ratnom pravu i o sigurnosti, ZONO, Zagreb, 1979 , str. 56.
} 
Zakon br.10 Kontrolnog savjeta u članu II (11) (c) zločin protiv čovječnosti definira kao: zvjerstvo i povrede, uključujući ali ne ograničavajući se na njih, ubistvo, istrebljenje, porobljavanje, deportacija, zatvaranje, mučenje, razbojništvo, ili druga nečovječna djela, izvršena protiv bilo kog civilnog stanovništva. Definiran je kao progon na političkoj, rasnoj ili vjerskoj osnovi bez obzira da li time vrše ili ne vrše povrede domaćih zakona zemlje gdje su zločini izvršeni.

Analizom gore navedenih definicija uočava se ključna razlika u vremenu počinjena. U Statutu Nirnberškog statuta govori se o zločinima počinjenim "prije ili za vrijeme trajanja rata", dok u Zakonu br.10 nije naglašen ovaj moment. Međutim, prema međunarodnom običajnom pravu ne postavlja se kao uslov da su zločini protiv čovječnosti počinjeni u oružanom sukobu.

\section{b) zločin protiv čovječnosti u Statutima Međunarodnih kaznenih sudova za bivšu Jugoslaviju i Ruandu}

U kontekstu definiranja zločina protiv čovječnosti u Statutima MKSJ i Međunarodnog kaznenog suda za Ruandu (dalje u tekstu MKSR) postoje izvjesne razlike na koje želim ukazati. U članu 5. Statuta MKSJ stoji: "Međunarodni tribunal je nadležan da krivično goni lica odgovorna za sljedeća krivična djela kada su počinjena u oružanom sukobu, bilo međunarodnog bilo unutarnjeg karaktera, i usmjerena protiv bilo kojeg civilnog stanovništva: a) ubistvo, b) istrjebljenje, c) porobljavanje, d) deportacija, e) zatvaranje, f) mučenje, g) silovanje, h) progoni na političkoj, rasnoj i vjerskoj osnovi, i druga nehumana djela."20

MKSR u članu 3. zločin protiv čovječnosti definira da je MKSR nadležan da krivično goni lica odgovorna za sljedeća krivična djela kada su počinjena kao dio rasprostranjenog ili sistematskog napada na civilno stanovništvo na nacionalnoj, političkoj, etničkoj, rasnoj ili vjerskoj osnovi: a) ubistva; b) istrebljenje; c) porobljavanje; d) deportacije; e) zatvaranje; f) mučenje;

20 Džon R.V.D Džouns, Stiven Pauls, Međunarodna krivična praksa, Fond za humanitarno pravo, Beograd, 2006, str. 180. 
g) silovanje; h) progoni na političkoj, rasnoj i vjerskoj osnovi; i) druga nehumana djela.

Statuti MKSJ i MKSR u pogledu definiranja zločina protiv čovječnosti imaju nekoliko ključnih razlika:

a) MKSR u članu 3. govori o napadu na civilno stanovništvo kao "dio rasprostranjenog ili sistematskog napada" a MKSJ nema ovakvu formulaciju. Međutim, MKSJ je preuzeo i priznao u svojoj praksi ovu formulaciju, tako da u postupcima pred ovim sudovima nema razlike.

b) MKSR u članu 3. predviđa da su zločini počinjeni na diskriminatorskoj osnovi (... na nacionalnoj, političkoj etničkoj, rasnoj ili vjerskoj) dok MKSJ diskriminaciju pominje samo u slučajevima progona (član 5. tačka h).

c) MKSR u članu 3. ne pominje postojanje oružanog sukoba kao osnove za počinjenje krivičnog djela zločin protiv čovječnosti dok MKSJ u članu 5. naglašava postojanje oružanog sukoba kao osnove za počinjenje ovog krivičnog djela.

\section{c) Zločin protiv čovječnosti u Statutu Međunarodnog kaznenog suda}

Rimski statut Međunarodnog krivičnog suda (dalje u tekstu MKS) propisuje nadležnost za najteža krivična djela usmjerena na cjelokupnu međunarodnu zajednicu. "Radi se o krivičnim djelima koja zadiru u srž ("core crimes") prema međunarodnom pravu."21 U članu 5. stav 1. propisana je stvarna nadležnost Suda koja je ograničena na najteža krivična djela, značajna za cjelokupnu međunarodnu zajednicu i to: a) zločin genocida; b) zločine protiv čovječnosti; c) ratne zločine; d) zločine agresije. U istom članu u stavu 2., Sud je nadležan za zločin agresije nakon što propisi doneseni prema članovima 121. i 123. ustanove njegova obilježja te odrede pretpostavke stvarne nadležnosti.

\footnotetext{
${ }^{21}$ Miodrag N. Simović, Milan Blagojević, Međunarodno krivično pravo, Apeiron, Banja Luka 2007, str. 31.
} 
Član 7. stav 1. Rimskog statuta MKS, definira zločin protiv čovječnosti kao bilo koje od niže opisanih djela, počinjenih u sklopu širokog ili sistematskog napada usmjerenog protiv civilnog stanovništva, uz znanje o tom napadu, kao što je: a) ubistvo; b) istrebljenje; c) porobljavanje; d) deportacije ili prisilni premještanje stanovništva; e) zatočenje ili drugo teško lišenje fizičke slobode kojim se narušavaju temeljna pravila međunarodnog prava; f) mučenje; g) silovanje, seksualno ropstvo, prisilna prostitucija, iznuđena trudnoća, prisilna sterilizacija ili svaki drugi oblik seksualnog nasilja slične težine; h) progon bilo koje prepoznatljive grupe ili zajednice na političkoj, rasnoj, nacionalnoj, etničkoj, kulturnoj, vjerskoj, spolnoj ili na drugoj osnovi koja je opšte priznata kao nedopustiva saglasno međunarodnom pravu. Ovaj oblik izvršenja može postojati u vezi sa svakom drugom radnjom izvršenja ovog krivičnog djela ili u vezi sa svakim krivičnim djelom iz nadležnosti ICC; i) prisilan nestanak lica; j) zločin aparthejda; k) ostala nečovječna djela slične prirode kojima se namjerno izazivaju teška stradanja ili ozbiljne tjelesne povrede ili povrede mentalnog zdravlja. ${ }^{22}$

U članu 7. stav 2. određena su značenja pojedinih pojmova koji se odnose na inkriminirajuće radnje učinjenja tako da: a) izraz "napad usmjeren protiv civilnog stanovništva" znači ponašanje koje uključuje višestruko činjenje djela navedenih u stavu 1. ovoga člana protiv nekog civilnog stanovništva, na osnovu ili u cilju državne politike ili politike neke organizacije da se takav napad počini; b) izraz "istrebljenje" uključuje namjerno nametanje životnih uvjeta kojima se, među ostalim, uskraćuje pristup hrani i lijekovima, s ciljem da dovede do uništenja dijela nekog stanovništva; c) izraz "porobljavanje" znači vršenje pojedine ili svih ovlasti koje proizlaze iz prava vlasništva nad nekom osobom i uključuje vršenje takve ovlasti u trgovini osobama, prvenstveno ženama i djecom; d) izraz "protjerivanje ili prisilni premještaj stanovništva" znači prisilno premještanje osoba putem progona ili drugih prisilnih mjera sa područja na kojemu zakonito borave a bez osnova predviđenih međunarodnim pravom; e) izraz "mučenje" znači namjerno nanošenje teške boli ili patnje,

${ }^{22}$ Isto, str. 133. 
bilo fizičke ili duševne, osobi kojoj je oduzeta sloboda ili koja je pod kontrolom optuženika osim onoga koje predstavlja bol ili patnju nastalu, sadržanu ili posljedičnu samo izvršavanju kakve zakonite kazne; f) izraz "prisilna trudnoća" znači nezakonito zatočenje žene koja je nasilno zatrudnjela, u namjeri uticanja na etnički sastav nekog stanovništva ili činjenja drugih teških povreda međunarodnog prava. Ova definicija ne može se tumačiti na bilo koji način kojim bi se utjecalo na nacionalne zakone koji se odnose na trudnoću; g) izraz "proganjanje" znači namjerno ili teško oduzimanje temeljnih prava, suprotno međunarodnom pravu, motivirano identitetom skupine ili zajednice; h) izraz "zločin apartheida" znači nečovječna djela slične prirode djelima opisanim u stavu 1. ovoga člana, počinjena u okviru institucionaliziranog režima sistematskog potlačivanja i dominacije jedne rasne skupine nad drugom rasnom skupinom ili skupinama i u namjeri održavanja takvog režima; i) izraz "prisilno nestajanje osoba" znači hapšenje, pritvaranje ili otimanje osoba od strane ili s dopuštenjem, podrškom ili pristankom države ili političke organizacije praćeno odbijanjem priznanja takvog oduzimanja slobode ili uskraćenjem obavijesti o sudbini ili smještaju tih osoba, s namjerom da im se uskrati pravna zaštita tokom dužeg vremenskog razdoblja.

\section{d) zločin protiv čovječnosti u KZ BiH}

Zločin protiv čovječnosti reguliran je članom $172 . \mathrm{KZ} \mathrm{BiH} \mathrm{i} \mathrm{on} \mathrm{u} 11$ tačaka regulira širok spektar ratnih zločina. Za našu analizu je posebno interesantan ovaj član, jer je najveći broj ratnih zločinaca, za zločine na prostoru Bosanske krajine osuđen za djela propisana ovim članom. Ovim članom regulirana su djela: a) ubistva, b) istrebljenje, c) odvođenje u ropstvo, d) deportacije i prisilno preseljenje stanovništva, e) zatvaranje i drugo teško oduzimanje fizičke slobode, f) mučenje, g) prisiljavanje druge osobe upotrebom sile ili prijetnje direktnim napadom na njen život ili tijelo ili na život i tijelo bliske osobe, na seksualni odnos ili s njim izjednačenu seksualnu radnju (silovanje), seksualno ropstvo, prisilnu prostituciju, prisilnu trudnoću, prisilnu sterilizaciju ili bilo koji drugi oblik teškog seksualnog nasilja, h) progon bilo koje grupe ili kolektiviteta na političkoj, rasnoj, nacionalnoj, etničkoj, kulturnoj, vjerskoj, spolnoj ili 
drugoj osnovi koja je univerzalno prihvaćena kao nedopustiva po međunarodnom pravu, u vezi $s$ bilo kojim krivičnim djelom iz ovog stava ovog člana, bilo kojim krivičnim djelom propisanim u ovom zakonu ili bilo kojim krivičnim djelom u nadležnosti Suda Bosne i Hercegovine, i) prisilni nestanak osoba, $\mathrm{j}$ ) zločin aparthejda, $\mathrm{k}$ ) druga nečovječna djela slične prirode, učinjena u namjeri nanošenja velike patnje ili ozbiljne fizičke ili psihičke povrede ili narušavanja zdravlja. ${ }^{23}$

Neki oblici ovog krivičnog djela bili su inkriminirani u članu 142. KZ SFRJ kao ratni zločin protiv civilnog stanovništva koja su učinjena za vrijeme rata, oružanog sukoba ili okupacije, ipak ovo krivično djelo je novo u našem krivičnom zakonodavstvu. Međunarodno pravna osnova za inkriminaciju ovog krivičnog djela je Rimski statut MKS koji u članu 7. propisuje krivično djelo zločin protiv čovječnosti. Član 172 . KZ BiH u cjelini je isti kao član 7. Rimskog statuta MKS uz razlike u određenim terminološkim značenjima. Zločin protiv čovječnosti "spada u najteža krivična djela koja se odnose na međunarodnu zajednicu kao cjelinu, jer su njime obuhvaćena ponašanja koja su nedopustiva po međunarodnom pravu koje je prihvaćeno u svim pravnim sistemima svijeta." ${ }^{24}$

Kako je već ranije naglašeno da je $\mathrm{KZ} \mathrm{BiH} \mathrm{u} \mathrm{članu} \mathrm{172.} \mathrm{stav} \mathrm{1.} \mathrm{potpuno}$ isto propisao ovo krivično djelo kao član 7. Rimskog statuta MKS nije potrebno šire pojašnjenje. Potrebno je istaknuti da se članom 172. KZ BiH štite individualna prava pojedinaca kao što su: život, zdravlje, sloboda, integritet (fizički i psihički), sloboda kretanja, pravo na život na određenim prostorima jednom riječju osnovna ljudska prava i slobode. U članu 172. stav 2. precizno i jasno su definirana pojedina značenja pojmova navedenih u stavu 1. radi potpunijeg i preciznijeg razumijevanja i praktične primjene ovog člana iz KZ BiH. Ovo krivično djelo čini onaj ko u okviru širokog ili sistematskog napada na civilno stanovništvo učini djela inkriminirana u članu 172. KZ BiH stav 1. Bitna odrednica ovog djela je rasprostranjenost

\footnotetext{
${ }^{23}$ Praktični vodič za gonjenje ratnih zločina u BiH, CEELI, Sarajevo, 2004, str.13. ${ }^{24}$ Z. Tomić, nav. dj., str. 418.
} 
i sistematičnost napada na civilno stanovništvo. ${ }^{25}$ "Pod takvim napadom se podrazumijeva takvo ponašanje koje uključuje višestruko počinjenje ovog djela protiv civilnog stanovništva na osnovi ili u cilju državne politike ili politike neke organizacije, u smislu da država ili neka organizacija potiču ili ohrabruju takve napade na civilno stanovništvo. To je ključni kriterij po kojem ovo krivično djelo dobija karakter međunarodnog krivičnog djela." 26

$\mathrm{KZ} \mathrm{BiH}$ za zločin protiv čovječnosti propisuje kaznu zatvora najmanje deset (10) godina ili kaznu dugotrajnog zatvora. Ukoliko ovo krivično djelo poredimo sa krivičnim djelom zločin genocida ili zločin protiv civilnog stanovništva možemo uvidjeti neke sličnosti ali i razlike. Ukoliko zločin protiv čovječnosti uporedimo sa zločinom genocida vidjet ćemo da se razlika prije svega ogleda u nepostojanju genocidne namjere (dolus specialis) kod zločina protiv čovječnosti. U osnovi ovog zločina nema namjere potpunoga ili djelomičnog istrebljenja neke nacionalne, rasne, etničke ili vjerske skupine. Druga razlika ogleda se u činjenici da se inkriminacijom krivičnog djela zločin protiv čovječnosti štite individualna prava pojedinaca, dok je kod genocida u prvom planu kolektivitet, bilo da je zasnovan na nacionalnoj, etničkoj, rasnoj i vjerskoj pripadnosti ciljne skupine. Kada se radi o različitostima ili sličnosti sa ratnim zločinima protiv civilnog stanovništva treba naglasiti glavu razliku koja se odnosi na vrijeme činjenja ovog krivičnog djela, odnosno zločin protiv čovječnosti može se počiniti i u vrijeme mira za razliku od ratnog zločina protiv civilnog stanovništva koji se može počiniti samo u vrijeme rata, oružanog sukoba ili okupacije. Bez obzira što ovo krivično djelo predstavlja novinu u zakonodavstvu BiH velik broj presuda pred Sudom $\mathrm{BiH}$ donesen je za počinitelje ovog krivičnog djela.

25 U Obrazloženju i Presudi MKSJ u predmetu Duško Tadić Pretresno vijeće je konstatiralo da "naglasak nije na pojedinačnoj žrtvi već na zajednici pri čemu je pojedinac viktimiziran ne zbog svojih pojedinih karakteristika već zbog svog pripadništva civilnom stanovništvu protiv kojeg su djela uperena." ICTY, Presuda pretresnog vijeća protiv Duška Tadića, paragraf 644 .

${ }^{26}$ Z. Tomić, nav. dj., str. 420. 


\section{Bitni elementi krivičnog djela}

\section{a) Izvršilac krivičnog djela}

Izvršenje krivičnog djela zločin protiv čovječnosti može učiniti svaka osoba bez obzira na svojstvo ili državljanstvo (delicta communia), ${ }^{27}$ međutim, najčešći izvršioci ovoga krivičnog djela su pripadnici vojnih, policijskih, političkih ili administrativnih struktura jedne od strana u sukobu. To su osobe koje direktno učestvuju u vojnim operacijama, ${ }^{28}$ ali i oni koji naređuju izvršenje istih. Naredbodavnu funkciju može imati svaka osoba koja svojim funkcijskim i hijerarhijskim položajem ima status naredbodavca. Naredbodavac je vojni komandant ${ }^{29}$ ili osoba koja po svom službenom položaju može izdati naredbu za izvršenje zakonom ili drugim propisima zabranjenih radnji. Komandna odgovornost može postojati samo u slučaju kada osoba zauzima komandni položaj i izdajući naredbu podređenim ili ne preduzimanjem mjera za sankcioniranje krivičnog djela koje su počinili njegovi podređeni. Izdavanje naredbe predstavlja jedan vid poticanja $^{30}$ koje je definirano u članu 7 (1) MKSJ, a koje ne mora da bude javno ili neposredno da bi bilo krivično djelo.

Komandanti i druge službene osobe koje po svom službenom položaju mogu izdavati naređenje moraju poduzeti određene mjere i aktivnosti kako bi njihovi podređeni bili upoznati sa zakonima i običajima rata, odnosno

27 Željko Horvatić, Zvonimir Šeparović, Kazneno pravo-posebni dio, Masmedia, Zagreb,1999, str. 150-164

${ }^{28}$ Pod ovim osobama podrazumijevaju se vojnici ili policajci koji direktno izvršavaju djela zabranjena navedenim Statutima i KZ BiH. Zapravo ovdje je riječ o licima koji su u direktnom mogućnosti da krše propisane zabrane i od njih ovisi da li će se poštovati ili ne navedena zakonska zabrana.

29 "Vojni komandant ili lice koje stvarno djeluje kao vojni komandant krivično je odgovorano za krivična djela iz nadležnosti Suda, koje su počinile snage pod njegovom ili njenom stvarnom komandom i nadzorom, odnosno stvarnom vlašću i nadzorom zato što nisu propisno kontrolisali te snage..." Član 28. stav 1. MKS.

30 "Poticanje znači navođenje drugog lica da izvrši krivično djelo." ICTY, Predmet IT98-33-T, Prvostepena presuda Radoslavu Krstiću, paragraf 601. 
sa Konvencijama i drugim propisima koji imaju za cilj zaštititi određene osobe i materijalna dobra. Istovremeno osoba koja imaju naredbodavnu ulogu dužna je protiv prekršitelja pravila međunarodnog prava da pokrenu disciplinski ili krivični postupak (Dopunski protokol I, član 87). ${ }^{31}$ Pitanje krivične odgovornosti je individualizirano i predstavlja osnovna načela međunarodnog prava. Statut MKSJ član 7(1) predviđa nekoliko vrsta odgovornosti i naglašava koja se odgovornost odnosi na optuženog. Ovo je vrlo važno iz razloga što su kazne različite ovisno od toga da li je neka osoba neposredni izvršilac, pomagač ili podstrekač. KZ BiH u članu 180. predviđa individualnu krivičnu odgovornost za krivična djela iz glavi XVII $\mathrm{KZ} \mathrm{BiH}$. KZ BiH, "prije svega predviđa individualnu krivičnu odgovornost za različite oblike saučesništva u širem smislu za sudjelovanje u ostvarenju nekog od osam navedenih krivičnih djela iz ove kategorije, sa odredbama o isključenju imuniteta s obzirom na službeni položaj. Druga odredba odnosi se na tzv. zapovjednu odgovornost, dok je trećom odredbom predviđena odgovornost i u slučaju postupanja po naređenju vlade ili nadređene osobe kojom je predviđena i mogućnost ublažavanja kazne."32

Statut MKS u članu 25. definira ličnu krivičnu odgovornost. Shodno navedenom članu stav 2. Svako ko počini krivično djelo iz nadležnosti Suda lično je krivično odgovoran i podložan kažnjavanju shodno ovome Statutu. Shodno članu 25. stav 3. Statuta MKS, svako je krivično odgovoran i podložan kažnjavanju za krivično djelo iz nadležnosti Suda ako: (a) takvo krivično djelo počini sam, u sudioništvu s drugom osobom ili putem druge osobe, bez obzira da li je ta druga osoba sama krivično odgovorna; (b) naredi, nagovori ili potakne počinjenje takvog krivičnog djela koje potom i bude počinjeno ili pokušano; (c) u cilju omogućenja počinjenja takvog djela pomaže, podupire ili na drugi način doprinese $u$ njegovom počinjenju ili pokušaju, uključujući i stavljanje na raspolaganje počinitelju sredstva za počinjenje djela; (d) na bilo koji drugi način doprinosi počinjenju ili pokušaju takvog krivično djela od strane skupine

\footnotetext{
${ }^{31}$ Međunarodne konvencije o ratnom pravu i o sigurnosti, nav. dj., str. 228.

32 Z. Tomić, nav. dj., str. 432.
} 
osoba koje djeluju sa zajedničkim ciljem. Takav doprinos mora biti namjeran i mora biti: (i) učinjen u cilju propagiranja kažnjive djelatnosti ili kažnjivog plana skupine koji uključuje počinjenje krivičnog djela iz nadležnosti Suda ili (i) učinjen uz poznavanje plana grupe da počini takvo krivično djelo: (e) u pogledu zločina genocida, direktno i javno potiče druge da ga počine; (f) pokuša takvo krivično djelo započinjanjem njegove radnje izvršenjem nekog njenog sastavnog dijela ali je ne dovrši uslijed okolnosti neovisnih od njegove namjere. Shodno ovom Statutu, nije kažnjiva osoba koja dobrovoljno i u cijelosti odbaci namjeru počinjenja te odustane od dovršenja radnje krivičnog djela ili spriječi nastupanje njezine posljedice.

\section{b) Vrijeme izvršenja i okolnosti izvršenja djela}

Vrijeme izvršenja ovog krivičnog djela vezujemo za vrijeme rata, oružanog sukoba i okupacije. Rat je intenzivan i kompleksan sukob država, vojnih saveza ili antagonističkih grupa unutar države u kojem se primjenjuje nasilje i vodi oružana borba. ${ }^{33} \mathrm{Da}$ bi se moglo govoriti o ratu mora postojati namjera, za rat se smatralo da makar jedna od sukobljenih strana mora imati namjeru ratovanja (tzv. "animus belligerendi"). ${ }^{34}$ Oružani sukob je osnovni sadržaj rata, to je uži pojam od rata. Osnovna karakteristika je upotreba oružanih sredstava i snaga radi postizanja određenih ciljeva koje je postavila jedna od strana u sukobu. Ovi sukobi mogu imati međunarodni i nemeđunarodni karakter. ${ }^{35}$ Pod okupacijom se smatra vojno zauzimanje cjelokupne ili djela teritorije tuđeg državnog područja i počinjenje tog prostora okupacionoj vlasti. Za ratnu okupaciju karakteristično je da se okupirano područje nesumnjivo nalazi pod vlašću okupatora $\mathrm{i} \mathrm{da}$ on provodi svoju vlast na okupiranom teritoriju. Okupacijom se državi onemogućava da vrši suverenu vlast na okupiranom

\footnotetext{
${ }^{33}$ Ahmet Kasumović, Ćamil Huseinbašić, Enciklopedijski riječnik odbrane BiH, Sejtarija, Sarajevo, 2000, str. 311.

${ }^{34}$ V. Đ. Degan, nav. dj., str. 839.

${ }^{35}$ Ova podjela je definirana u Ženevskim konvencijama I-IV, Dopunskim protokolima I i II, Rimskim statutom MKS i drugim međeunarodno pravnim aktima.
} 
prostoru. Međunarodno pravo nastoji regulirati okupaciju u cilju zaštite stanovništva na okupiranom području ${ }^{36}$ i ograničenja vlasti okupatora. $\mathrm{U}$ konačnici se može reći da je za postojanje krivičnog djela zločin protiv čovječnosti potrebno postojanje stvarnog neprijateljstva, odnosno borbeno djelovanje koje za posljedicu ima činjenje radnji koje su kažnjive po međunarodnom pravu.

\section{c) Objekt zaštite}

Opći i zajednički objekt zaštite u ovom krivičnom djelu je čovječnost i vrijednosti zaštićene međunarodnim pravom. Pasivni subjekt krivičnog djela zločin protiv čovječnosti je civilno stanovništvo bez obzira na pripadnost određenoj skupini ili zajednici. Ovim se štite osnovna ljudska prava i slobode. Član 172. stav 1 . KZ BiH propisuje objekte zaštite. Ženevske konvencije u članu 3. također ističe čovječnost u prvi plan. Dakle objekt zaštite ovog krivičnog djela je civilno stanovništvo. Ovo krivično djelo usmjereno je prije svega na teška kršenja ljudskog dostojanstva i opće civilizacijskih principa. Objekt zaštite u ovom slučaju nisu pojedinačni i sporadični događaji usmjereni prema pojedinim zaštićenim osobama nego je to rasprostranjeno i sistematično činjenje zločina podržano direktno ili indirektno od političkih ili vojnih struktura počinilaca zločina. Najčešće žrtve su civili mada mogu biti i vojne osobe koje ne učestvuju u oružanim sukobima.

\section{Pravomoćne presude izrečene pred MKSJ i Sudom BiH za zločine na prostoru Bosanske krajine}

Do sada su pred MKSJ i Sudom Bosne i Hercegovine, izrečene pravomoćne presude za krivično djelo zločin protiv čovječnosti za zločine počinjene na prostorima Bosanske krajine, istovremeno jedan broj predmeta je u fazi istrage, suđenja ili u žalbenom postupku. Do sada je pred Haškim sudom za zločine na prostoru Bosanske krajine izrečeno 16 pravomoćnih presuda sa ukupnom kaznom zatvora od 267 godina. Pred

\footnotetext{
36 Ženevska konvencija o zaštiti građanskih osoba za vrijeme rata od 12. augusta 1949. godine, član 49.
} 
ovim Sudom okončani su postupci za 4 osobe zbog smrti i to: postupak protiv Slobodana Miloševića, Milana Kovačevića, Momira Talića i Sime Drljače. Istovremeno pred Haškim Sudom u toku su suđenja četiri (4) predmeta za zločine na prostoru Bosanske krajine. Od ukupnog broja optuženih i osuđenih pred ovim Sudom najviše je slučajeva koji se odnose na Bosansku Krajinu. Pred Haškim tribunalom najviše osoba osuđeno je za zločine počinjene u Prijedoru. Među osuđenima su:

1. Milomir Stakić (IT-97-24) osuđen na četrdeset (40) godina zatvora za krivično djelo zločin protiv čovječnosti počinjen na području općine Prijedoru i to za: istrebljenje, ubistvo, progoni (koji su, između ostalog, počinjeni ubistvom, mučenjem, fizičkim nasiljem, silovanjem, seksualnim zlostavljanjem, stalnim ponižavanjem i degradiranjem, deportacijom masovnih razmjera). ${ }^{37}$

2. Milan Martić (IT-95-11) osuđen na trideset pet (35) godina zatvora za zločine počinjene na području sjeverozapadne Bosne i to: za ubistvo, progone na političkoj, rasnoj i vjerskoj osnovi, okrutno postupanje, zatvaranje, deportacije, pljačkanje javne ili privatne imovine, bezobzirno uništavanje sela i razaranje koje nije opravdano vojnom nuždom, mučenje, nehumana djela, napade na civile, što predstavlja zločin protiv čovječnosti i kršenje zakona i običaja ratovanja na osnovu individualne odgovornosti i odgovornosti nadređenog.

3. Radoslav Brđanin (IT-99-36) osuđen na kaznu zatvora od 30 godina. Osuđen za zločini protiv čovječnosti i to za djela: progone, mučenje, deportacije, nehumana djela (prisilno premještanje), bezobzirno razaranje gradova, naselja i sela koje nije opravdano vojnom nuždom, uništavanje ili hotimično nanošenje štete ustanovama namijenjenim religiji, hotimično lišavanje života; mučenje.

4. Zoran Žigić osuđen na 25 godina zatvora za zločine u Omarskoj i Keratermu, za zločin protiv čovječnosti (progone na političkoj, rasnoj ili

\footnotetext{
37 Pravosnažno okončani predmeti pred MKSJ objavljeno u Zločin i kazna, Fond otvoreno društvo BiH, Sarajevo, 2006, str. 29-85.
} 
vjerskoj osnovi, mučenje i okrutno postupanje), kršenje zakona i običaja rata.

5. Momčilo Krajišnik osuđen na 20 godina zatvora za zločin: progoni na političkoj, rasnoj ili vjerskoj osnovi, deportacije, nehumana djela (zločini protiv čovječnosti), prisilno premještanje u Bijeljini, Bratuncu, Zvorniku, Bosanskoj Krupi, Sanskom Mostu.

6. Mlađo Radić osuđen na 20 godina zatvora za zločine u Omarskoj i Keratermu i to za djelo: progoni na političkoj, rasnoj ili vjerskoj osnovi, ubistva i nehumana djela (zločine protiv čovječnosti).

7. Duško Tadić (IT-94-1) osuđen na 20 godina zatvora za zločine u općini Prijedor i to za djela: hotimičnog lišavanja života; mučenja ili nečovječnog postupanja; hotimično nanošenje teške patnje ili teške tjelesne povrede ili ugrožavanje zdravlja (teške povrede Ženevskih konvencija iz 1949.).

8. Darko Mrđa (IT 02-59) Trnopolje i Vlašić, osuđen na 17 godina zatvora za zločin na Korićanskim stijenama i to za djela: ubistvo i nehumana djela (kršenje zakona i običaja ratovanja i zločin protiv čovječnosti).

9. Duško Sikirica (IT- 95-8) osuđen na 15 godina za zločine u logoru Keraterm i to za progone na političkoj, rasnoj ili vjerskoj osnovi (zločine protiv čovječnosti).

10. Biljana Plavšić, osuđena na 11 godina zatvora za zločin: progon na političkoj rasnoj ili vjerskoj osnovi (zločine protiv čovječnosti). Biljana Plavšić je osuđena da je učestvovala, planirala, podsticala, kreirala i sprovodila progon Bošnjaka i Hrvata na području Bosanske krajine u gradovima: Banja Luka, Bosanska Krupa, Bosanski Novi, Bosanski Petrovac, Ključ, Kotor-Varoš, Prijedor, Prnjavor, Sanski Most.

11. Predrag Banović (IT-02-65/1 od 28.10.2003. godine) osuđen 8 godina za zločine u Omarskoj i Keratermu i to za djelo: progon na političkoj, rasnoj ili vjerskoj osnovi (zločini protiv čovječnosti ).

12. Miroslav Kvočka (IT 98-30/1) osuđen na 7 godina zatvora za zločine u Keratermu i Trnopolju i to za progone na političkoj, rasnoj ili vjerskoj osnovi, ubistvo i mučenje (zločini protiv čovječnosti). 
13. Milojica Kos osuđen na 6 godina zatvora za zločine u Omarskoj i Keratermu i to za progone na političkoj, rasnoj ili vjerskoj osnovi, ubistva i mučenje (zločini protiv čovječnosti).

14. Damir Došen osuđen na 5 godina zatvora za zločine u logoru Keraterm, za progon na političkoj, rasnoj ili vjerskoj osnovi (zločini protiv čovječnosti).

15. Dragoljub Prcać osuđen na 5 godina zatvora za zločine u Omarskoj i Keratermu za progone na političkoj, rasnoj ili vjerskoj osnovi, ubistvo i mučenje (zločini protiv čovječnosti).

16. Dragan Kolundžija osuđen na 3 godine zatvora za zločine u logoru Keraterm i to za progone na političkoj, rasnoj i vjerskoj osnovi (zločine protiv čovječnosti).

Sud Bosne i Hercegovine uspostavljen je Odlukom Visokog predstavnika za Bosnu i Hercegovinu od 8. maja 2002. godine, a Zakon o Sudu Bosne i Hercegovine donesen je 11. jula 2002. godine. ${ }^{38}$ Sud Bosne i Hercegovine ima tri odjeljenja: krivično, upravno i apelaciono. Krivično odjeljenje ima tri odjela, Odjel I za ratne zločine, Odjel II za organizirani kriminal i Odjel III za opšti kriminal. Upravno odjeljenje ima parnični referat i jedno vijeće. Apelaciono odjeljenje ima Odjel I za ratne zločine, Odjel II za organizirani kriminal, Odjel III za opšti kriminal i žalbe na odluke Upravnog odjeljenja. Odjel I za ratne zločine preuzeo je jedan broj predmeta od Haškog tribunala i počeo je sa suđenjima za ratne zločine počinjene u Bosni i Hercegovini. Za zločine protiv čovječnosti počinjene na prostoru Bosanske krajine pravomoćno je osuđeno deset (10) osoba na ukupnu zatvorsku kaznu od stotinu pedeset četiri (154) godine zatvora. Sud Bosne i Hercegovine izrekao je sljedeće pravomoćne presude:

1. Dušan Fuštar (X-KR-06/200-1) osuđen na devet (9) godina zatvora za zločine počinjene u logoru Keraterm (zločin protiv čovječnosti iz člana

\footnotetext{
38 Zakon je usvojen od strane oba doma Parlamenta Bosne i Hercegovine, objavljen u Službenom glasniku Bosne i Hercegovine, br. 16/02 od 11. jula 2002. godine.
} 
172. stav 1 . tačka $h$, a u vezi sa članom 29 i 180 , stav 1 . Krivičnog zakona Bosne i Hercegovine).

2. Damir Ivanković (X-KR- 08/549-1) osuđen na četrnaest (14) godina zatvora za zločine počinjene na Korićanskim stijenama (zločin protiv čovječnosti iz člana 172. stav 1 . tačka $h$, u vezi sa tačkama $a, d, e i k$, a sve u vezi sa članom 180. stav 1. Krivičnog zakona Bosne i Hercegovine).

3. Nikola Kovačević (X-KRŽ-05/40) osuđen na dvanaest (12) godina zatvora za zločine počinjene na području općine Sanski Most (zločin protiv čovječnosti iz člana 172 . stav 1 . tačka $h$ ) u vezi sa tačkama $a, e, f i k$, a sve u vezi sa članom 180. stav 1. Krivičnog zakona Bosne i Hercegovine).

4. Željko Mejakić (X-KR/06/200) osuđen na dvadeset jednu (21 godinu zatvora za zločine počinjene u logoru Omarska (krivično djelo zločin protiv čovječnosti iz člana 172. stav 1. Krivičnog zakona Bosne i Hercegovine i to: iz tačke $a$ ) lišenje druge osobe života (ubistvo), iz tačke e) zatvaranje (samovoljno i protupravno zatočenje zatočenika u logore), iz tačke $f$ ) mučenje (premlaćivanja i ostali oblici fizičkog nasilja), iz tačke $g$ ) seksualno nasilje (silovanja i ostali oblici seksualnog zlostavljanja), iz tačke k) druga nečovječna djela (zatočenje u nehumanim uslovima, šikaniranje, ponižavanje i drugo psihičko zlostavljanje) i iz tačke $h$ ) progon, a sve u vezi sa članom 29. i članom 180. stav 1. i 2. Krivičnog zakona Bosne i Hercegovine.

5. Momčilo Gruban (X-KRN-06/200) osuđen na jedanaest (11) godina zatvora za zločine počinjene u logoru Omarska (krivično djelo zločin protiv čovječnosti iz člana 172. stav 1. Krivičnog zakona Bosne i Hercegovine i to: iz tačke $a$ ) lišenje druge osobe života (ubistvo), iz tačke e) zatvaranje (samovoljno i protupravno zatočenje zatočenika u logore), iz tačke f) mučenje (premlaćivanja i ostali oblici fizičkog nasilja), iz tačke $g$ ) seksualno nasilje (silovanja i ostali oblici seksualnog zlostavljanja), iz tačke k) druga nečovječna djela (zatočenje u nehumanim uslovima, šikaniranje, ponižavanje i drugo psihičko zlostavljanje) i iz tačke h) progon, a sve u vezi sa članom 29. i članom 180. stav 1. i 2. Krivičnog zakona Bosne i Hercegovine. 
6. Duško Knežević ( X-KRN-06/200) osuđen na trideset jednu (31) godinu zatvora za zločine počinjene u logoru Keraterm ( krivično djelo zločin protiv čovječnosti iz člana 172. stav 1. Krivičnog zakona Bosne i Hercegovine i to: iz tačke $a$ ) lišenje druge osobe života (ubistvo), iz tačke f) mučenje (premlaćivanja i ostali oblici fizičkog nasilja), iz tačke $k$ ) druga nečovječna djela (zatočenje u nehumanim uslovima, šikaniranje, ponižavanje i drugo psihičko zlostavljanje) i iz tačke $h$ ) progon (sve radnje opisane u tački 3. i 5. optužnice), a u vezi samo sa tačkom 3 optužnice, iz tačke $g$ ) seksualno nasilje (silovanja i ostali oblici seksualnog zlostavljanja) a sve u vezi sa članom 29. i članom 180. stav 1. Krivičnog zakona Bosne i Hercegovine.

7. Jadranko Palija (X-KRŽ-06/290) osuđen na dvadeset osam (28) godina za zločine počinjene na području općine Sanski Most (krivično djelo zločin protiv čovječnosti iz člana 172. stav 1. Krivičnog zakona Bosne i Hercegovine i to: iz tačke a) lišenje druge osobe života (ubistvo), e) zatvaranje (samovoljno i protupravno zatočenje zatočenika u logore), iz tačke $g$ ) seksualno nasilje (silovanja i ostali oblici seksualnog zlostavljanja), iz tačke $k$ ) druga nečovječna djela (zatočenje u nehumanim uslovima, šikaniranje, ponižavanje i drugo psihičko zlostavljanje), zločine protiv civilnog stanovništva član 173. stav 1 Krivičnog zakona Bosne i Hercegovine i to tačke $a$ ), $c$ ) , e) a sve u vezi sa članom 180. stav 1 . Krivičnog zakona Bosne i Hercegovine.

8. Marko Samardžija (X-KRŽ- 05/07) osuđen na sedam (7) godina za zločine počinjene na području općine Ključ (krivično djelo zločini protiv čovječnosti iz člana 172. stav 1 iz tačke $e$ ) zatvaranje (samovoljno i protupravno zatočenje zatočenika u logore), sve u vezi sa članom 29. i 180. stav 1. Krivičnog zakona Bosne i Hercegovine).

9. Gordan Đurić (X-KR-08/549-2) osuđen na osam (8) godina zatvora za zločine počinjene na Korićanskim stijenama (krivično djelo zločin protiv čovječnosti iz člana 172. stav 1. tačka $h$ ) u vezi sa tačkama $a$ ), d), e) i $k$ ), a sve u vezi sa članom 180. stav 1. Krivičnog zakona Bosne i Hercegovine).

10. Ljubiša Četić (X-KR-08-549-3) osuđen na trinaest (13) godina zatvora za zločine počinjene na Korićanskim stijenama (krivično djelo zločin 
protiv čovječnosti iz člana 172. stav 1 . tačka $h$ ) u vezi sa tačkama $a$ ), d), e) $\mathrm{i} k$ ), a sve u vezi sa članom 180. stav 1. Krivičnog zakona Bosne i Hercegovine).

\begin{tabular}{|l|l|l|l|}
\hline NAZIV SUDA & $\begin{array}{l}\text { BROJ } \\
\text { PRAVOSNAŽNO } \\
\text { OSUĐENIH LICA }\end{array}$ & $\begin{array}{l}\text { UKUPNA } \\
\text { VISINA } \\
\text { KAZNI }\end{array}$ & $\begin{array}{l}\text { POSTUPCI U } \\
\text { TOKU }\end{array}$ \\
\hline MKSJ & 16 & 267 & 4 \\
\hline SUD BiH & 10 & 154 & 15 \\
\hline Ukupno & 28 & 421 & 19 \\
\hline
\end{tabular}

Tabela 1. Pravomoćne presude za zločin protiv čovječnosti nad Bošnjacima i Hrvatima Bosanske krajine

Haški tribunal je najviše osudio osobe za zločine protiv čovječnosti počinjene na području općine Prijedor. Navedena kvalifikacija i krivična djela u svim presudama pred MKSJ za Bosansku krajinu su potvrđena, a posebno za prostore općina Prijedor, Sanski Most, Ključ, Bosanski Novi, Bihać, Bosanski Petrovac. Kada se govori o kažnjavanju i visini kazni one se kreću u rasponu od tri (3) do četrdeset (40) godina zatvora. Najviše kazni izrečeno je u rasponu od deset (10) do dvadeset (20) godina zatvora. A kada se radi o pojedinačnim djelima najčešća kvalifikacija djela su: ubistva, progoni na političkoj, rasnoj i vjerskoj osnovi, mučenja, zatvaranja, silovanja. Pored ovih djela navedena su u nekoliko presuda teška kršenja Ženevskih konvencija. Pred MKSJ vodi se nekoliko slučajeva u kojima su pojedine osobe optužene za najteža krivična djela genocida, a odnose se na zločine na prostoru Bosanske krajine.

Sud $\mathrm{BiH}$ za zločin protiv čovječnosti počinjen na prostoru Bosanske krajine pravomoćno je osudio deset (10) osoba na ukupnu zatvorsku kaznu od stotinu pedeset četiri (154) godine. Istovremeno se pred Sudom Bosne i Hercegovine vodi postupak u predmetima protiv 15 osoba za zločine počinjene na prostoru Bosanske krajine. Jedan broj predmeta vraćenih iz MSKJ na procesuiranje Sudu Bosne i Hercegovine i predmeti pokrenuti 
od strane nadležnih organa Bosne i Hercegovine procesuiraju se na osnovu $\mathrm{KZ} \mathrm{BiH.}$

Presude se odnose za zločine počinjene u općinama Prijedor, Sanski Most i Ključ. Raspon kazni kreće se od trideset jedne (31) do sedam (7) godina. Najviše kaznenih djela odnose se na tačke $a, d, e, f, g, k$ člana 172 . KZ BiH. Pred Sudom Bosne i Hercegovine vodi se nekoliko predmeta protiv određenih osoba za zločine počinjene u Ključu, Prijedoru, Bosanskoj Krupi.

\section{Zaključak}

Zločin protiv čovječnosti kao jedan od najtežih zločina nije neki pojedinačni, nego rasprostranjen i sistematičan događaj u okviru planirane i šire zločinačke politike. U ovome se ogleda i razlikuje od ratnog zločina protiv civilnog stanovništva, iako imaju dosta zajedničkih elemenata, naročito u načinu izvršenja djela. Kada su u pitanju kršenja pravila i običaja rata i Ženevskih konvencija na prostoru Bosanske krajine, sa sigurnošću se može tvrditi da su ona kršena bez ograničenja. Najčešće su civili i civilni objekti bili mete napada i prema njima se postupalo krajnje nehumano, necivilizirano i brutalno. Ne uvažavajući i u praksi potpuno ignorirajući zaštićene osobe, vršena su masovna ubijanja, nanošenje teških tjelesnih i duševnih povreda, odvođenje u logore, deportacije, seksualno zlostavljanje u svim oblicima, progoni i dr. Kada su u pitanju kršenja međunarodnog humanitarnog prava na području Bosanske krajine, posmatrano sa aspekta optužnica i pravomoćno osuđujućih presuda, najveći broj kvalifikacija je zločin protiv čovječnosti.

\section{Literatura}

1. Ahmet Kasumović, Ćamil Huseinbašić, Enciklopedijski rječnik odbrane $\mathrm{BiH}$, Sejtarija, Sarajevo, 2000.

2. Antonio Kaseze, Medunarodno krivično pravo, Dosije, Beograd, 2005.

3. Džon R.V.D Džouns, Stiven Pauls, Medunarodna krivična praksa, Fond za humanitarno pravo, Beograd, 2006.

4. Lassa Oppenheim, International law, Vol.1, treće izdanje, 1920. 
5. Miodrag N. Simović, Milan Blagojević, Medunarodno krivično pravo, Apeiron, Banja Luka, 2007.

6. Praktični vodič za gonjenje ratnih zločina u BiH, CEELI, Sarajevo, 2004.

7. Vahakn Dadrian, The History of the Armenian Genocide (1995).

8. Vladimir Đuro Degan, Medunarodno pravo, Pravni fakultet u Rijeci, Rijeka, 2000.

9. Zbirka propisa, Međunarodne konvencije o ratnom pravu i o sigurnosti, ZONO, Zagreb, 1979.

10. Zločin i kazna, Fond otvoreno društvo BiH, Sarajevo, 2006.

11. Zvonimir Tomić, Krivično pravo II-posebni dio, Pravni fakultet Sarajevo, Sarajevo, 2007.

12. Željko Horvatić, Zvonimir Šeparović, Kazneno pravo-posebni dio, Masmedia, Zagreb, 1999.

13. Službeni glasnik $\mathrm{BiH}$ br. 3/03.

14. Službeni glasnik BiH br. 37/ 03.

15. Službeni glasnik BiH br. 54/04.

16. Službeni glasnik BiH br. 61/04.

17. ICTY, Presuda pretresnog vijeća protiv Duška Tadića, Predmet: IT-94-1, Den Haag, 16. juli 1997.

18. ICTY, Prvostepena presuda Radoslavu Krstiću, Predmet: IT-98-33-T, Den Haag, 2. august 2001. 
Mujo Begic, $\mathrm{PhD}^{39}$

\section{CRIMINAL OFFENSE 'CRIME AGAINST HUMANITY' IN THE FINAL VERDICTS FOR CRIMES COMMITTED IN THE BOSNIAN KRAJINA}

\section{Abstract}

Criminal offense 'Crime against humanity' in the final verdicts passed against individuals for crimes committed in the Bosnian Krajina is the most common criminal sanction imposed by the International Criminal Tribunal for the former Yugoslavia (hereinafter ICTY) and the Court of Bosnia and Herzegovina (hereinafter the Court of BiH). A crime against humanity is directed towards the values characteristic for the whole of humanity and the general civilization values. By defining this offense in the Statutes of international courts and the Criminal Code of Bosnia and Herzegovina (hereinafter $\mathrm{CC} \mathrm{BiH}^{40}$ ) it becomes possible to punish serious violations of human rights that are products of a broader criminal policy. In our criminal law this criminal offense was not covered by the Criminal Code of Yugoslavia (hereinafter CC SFRY), but is defined by the Criminal Code of Bosnia and Herzegovina.

Although crimes against humanity until the emergence of $C C \mathrm{BiH}$ were not defined by the CC SFRY, some forms of crimes against humanity contain identical offenses that were previously defined as a war crime against the civilian population if they were committed in times of war, armed conflict or occupation. Regardless of the fact that this crime represents a novelty in the criminal legislation of Bosnia and Herzegovina, a number of criminal sanctions were imposed before the Court for this serious crime. A number of final judgments were handed down by the ICTY for crimes committed in the Bosnian Krajina. By defining this crime, Bosnia and Herzegovina has at the

\footnotetext{
39 The Missing Persons Institute in Bosnia and Herzegovina.

${ }^{40} \mathrm{CC} \mathrm{BiH}$ was adopted on March 1, 2003. ('Official Gazette of Bosnia and Herzegovina', no. 3/03). A consolidated text was published in the 'Official Gazette' no. 37/03. The amendments were carried out on several occasions and have been published in the 'Official Gazzette', no. 54/04 and 61/04.
} 
same time fulfilled its international legal and constitutional obligation. This paper offers the analysis of the essential elements of crimes against humanity with a special focus on the final judgment handed down for crimes committed in the Bosnian Krajina.

Keywords: crime against humanity, international humanitarian law, war, armed conflict, the civilian population, murder, extermination, enslavement, deportation, imprisonment, torture, rape, persecution, inhumane acts. 
الأستاذ المساعد مويو بيغيتش 1

جريمة "الإبادة الجماعية ضد الإنسانية" في القرارات سارية المفعول للمحكمة على الجنايات المرتكبة في منطقة "بوسنسكا كرايينا"

\section{خلاصة}

جريمة "الإبادة الجماعية ضد الإنسانية" في القرارات سارية المفعول للمحكمة على

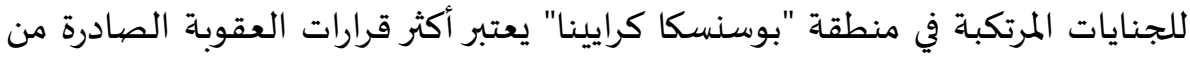

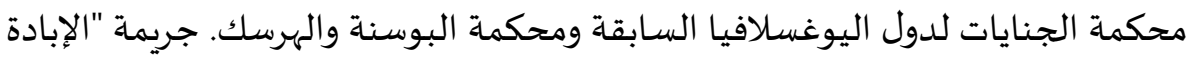

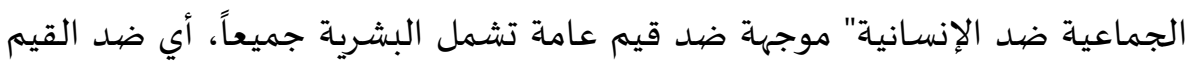

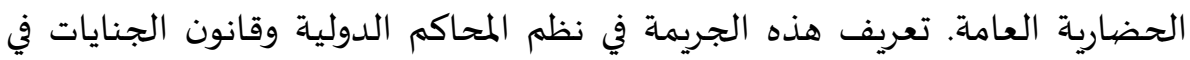

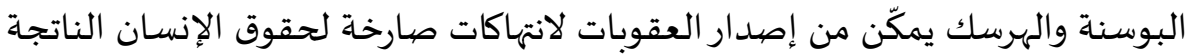

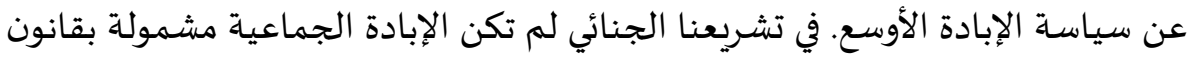

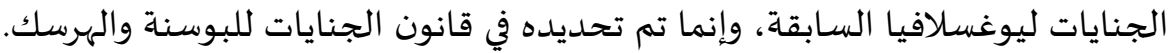

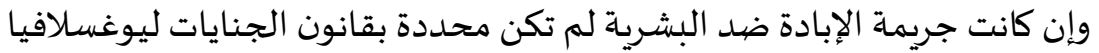

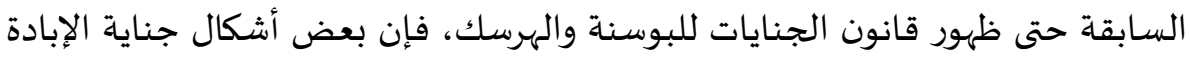

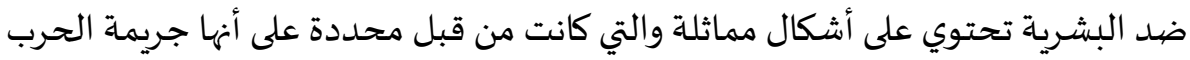

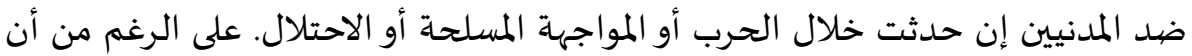

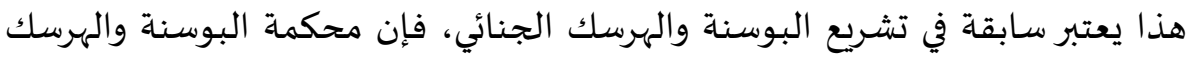

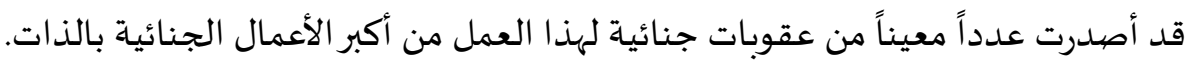

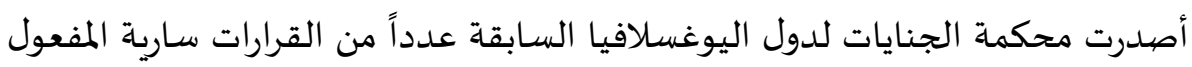

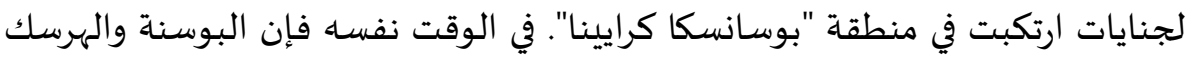
ومن خلال تحديد هذا الجناية قد نفذت واجبها الدستوري والواجب الذي كاني اندان يمليه عليها القانون الدولي.

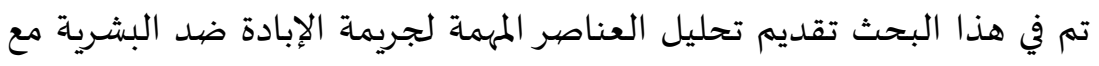
التفات خاص إلى القرارات سارية المفعول لجنايات ارتكبت في منطقة "بوسانسكا كرايينا".

اء المعهد المتخصص في البحث عن الأشخاص المفقودين. 


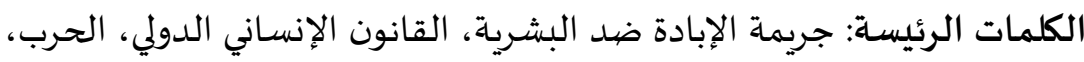

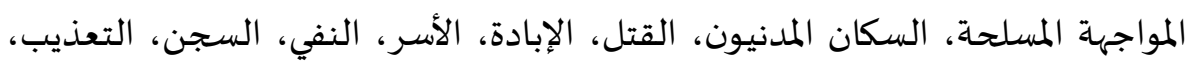

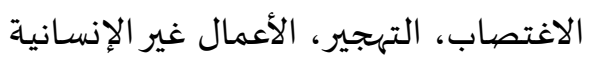

